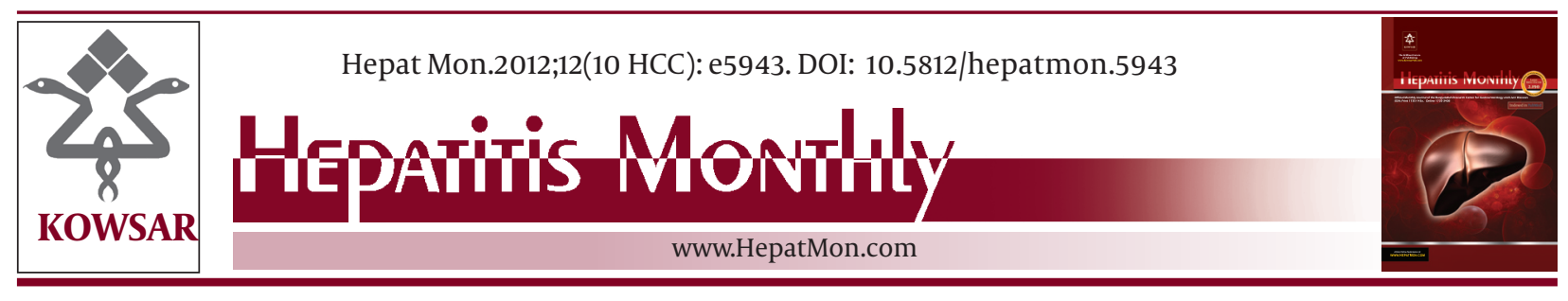

\title{
Risk of Hepatocellular Carcinoma in Workers Exposed to Chemicals
}

\author{
Mario Uccello ${ }^{1}$, Giulia Malaguarnera ${ }^{1^{*}}$, Thea Corriere ${ }^{1}$, Antonio Biondi ${ }^{2}$, Francesco Basile ${ }^{2}$, \\ Mariano Malaguarnera ${ }^{1}$ \\ ${ }^{1}$ Research Center “The Great Senescence”, University of Catania, Catania, Italy \\ ${ }^{2}$ Department of General Surgery, University of Catania, Catania, Italy
}

\begin{tabular}{l}
\hline A R T I C L E I N F O \\
\hline Article type: \\
Review Article \\
\hline Article history: \\
Received: 20 Jul 2011 \\
Revised: 28 Sep 2011 \\
Accepted: 08 Oct 2011 \\
\hline
\end{tabular}

Keywords:

Carcinoma, Hepatocellular

Occupational Exposure

Vinyl Chloride

Solvents

Pesticides

Polychlorinated Biphenyls

Arsenic

\begin{abstract}
A B S T R A C T
Context: Studies on experimental animals have shown liver is a common target of chemical carcinogens; this might suggest that occupational exposure to chemicals is another risk factor for HCC. However, the relationship between occupation and liver cancer has not been extensively studied, with the exception of the known association between vinyl chloride and angiosarcoma of the liver.

Evidence Acquisition: A MEDLINE and conventional search of the past 50 years of the medical literature was performed to identify relevant articles on incidence and mechanisms of HCC due to occupational exposure to chemicals. Several important edited books and monographs were also identified and reviewed.

Results: While laboratory data clearly indicate that the liver is an important target of chemical carcinogenesis, epidemiological studies provide very limited evidence on occupational risk factors for HCC. Nevertheless, we found some case reports and epidemiological data showing a moderately increased risk of HCC development in people exposed to vinyl chloride, organic solvents, pesticides, polychlorinated biphenyls, and arsenic. Conclusions: Occupational exposure to chemicals may be another risk factor for HCC development, but the interpretation of currently available findings is limited by the small number of studies, questionable accuracy of the diagnosis of liver cancer, and potential confounding or modifying factors such as chronic hepatitis virus infection and alcohol consumption. Further relevant investigations are required for clarifying the actual contribution of occupational exposure to chemicals in HCC development.
\end{abstract}

Copyright ๑2011 Kowsar M. P. Co. All rights reserved.

Implication for health policy/practice/research/medical education:

Treatment of chronic hepatitis B with antiviral agents averts the development of cirrhosis and hepatocellular carcinoma. Identification of markers likely to predict a favourable outcome in treated patients is therefore essential. HBsAg may be one such marker.

Please cite this paper as:

Uccello M, Malaguarnera G, Corriere T, Biondi A, Basile F, Malaguarnera M. Risk of Hepatocellular Carcinoma in Workers Exposed to Chemicals. Hepat Mon. 2012;12(10 HCC): e5943. DOI: 10.5812/hepatmon.5943

\section{Context}

Toxic environmental exposures, including workplace exposures, are responsible for a substantial number of cancer cases. Exact estimation of this number is not possible because of gaps in the data on exposure, inter- actions with lifestyle carcinogens, and differences in the exposure patterns in different countries (1). Few studies have assessed occupational exposures. Despite the progressive improvement in measures to reduce workplace carcinogenic exposures in most countries, occupational exposure to carcinogens is still a remarkable health risk

\footnotetext{
*Corresponding author: Giulia Malaguarnera, Research Center “The Great Senescence”, University of Catania, Catania Ospedale Cannizzaro, Viale Messina, 82995125 Catania, Italy. Tel:+39-957262008, Fax: +39-957262011. E-mail: malaguar@unict.it

DOI: $10.5812 /$ hepatmon.5943

Copyright@ 2012 Kowsar Corp. All right reserved.

This is an Open Access article distributed under the terms of the Creative Commons Attribution License (http://creativecommons.org/licenses/by/3.0), which permits unrestricted use, distribution, and reproduction in any medium, provided the original work is properly cited.
} 
worldwide, particularly in developing countries with intense and uncontrolled exposure to common environmental carcinogens (1-3). Hepatocellular carcinoma (HCC) represents a major health problem worldwide. It is the dominant form of primary liver cancer and the third leading cause of cancer-related deaths, accounting for over half a million deaths per year (4-6). Environmental factors play a key role in the development of HCC. Approximately 70\%-90\% of HCC patients have an established history of chronic liver disease and cirrhosis, whose major risk factors include alcoholic liver disease and chronic infection with hepatitis B virus (HBV) and hepatitis $\mathrm{C}$ virus (HCV) $(7,8)$. Additional risk factors for developing HCC include nonalcoholic steatohepatitis (NASH), intake of aflatoxin-contaminated food, diabetes, obesity, cigarette smoking, certain hereditary conditions such as hemochromatosis, and certain metabolic disorders (9-11).

The relationship between occupation and liver cancer has not been extensively studied, with the exception of the known association between vinyl chloride monomer (VCM) and angiosarcoma of the liver (ASL) (12). However, occupational exposure to toxic chemicals may be associated with a high risk of HCC. This hypothesis seems plausible, especially because the liver is the most common site of tumor origin in experimental animals treated with chemical carcinogens (13). Moreover, some epidemiological studies on cancer incidence or mortality among individuals in occupations that usually involve exposure to chemicals have shown that such individuals have a moderately high risk of primary liver cancer (14-17). According to the latest evaluation reports of the International Agency for Research on Cancer (IARC), only VCM and trichloroethylene (TCE) have been found to have a carcinogenic effect on human liver (Table 1). However, recent data clearly indicate that the liver is a potential target of other occupational carcinogens. In this paper, we have summarized the current knowledge about selected chemicals and their possible role as occupational risk factors of HCC.

\section{Evidence Acquisition}

A MEDLINE and conventional search of the past 50 years of the medical literature was performed. In order to identify relevant articles on incidence and mechanisms of HCC due to occupational exposure to chemicals, we first performed a MEDLINE search of articles from 1966 onward. Secondly, we searched the reference lists of the articles initially retrieved for additional studies. This method of cross-checking was continued until no further publications were found. In case of multiple publications on the same study population, we used the most recent publication. Several important edited books and monographs were identified through "Web of Science" searching, bibliography review, and expert consultation. Particular emphasis was placed on the "IARC
Monographs on the Evaluation of Carcinogenic Risks to Humans", performed by international working groups of independent scientists and often used as the basis for regulatory classification. Nevertheless, we took care of including the evidence emerged after the publication of the latest IARC monographs. With regards to representative animal studies, epidemiological investigations, case reports and other relevant data, only reports that have been published or accepted for publication in the openly available scientific literature were reviewed. Material provision was conducted independently by each author, and any discrepancies among reviewers were resolved by consensus. Eligible material was selected for evaluation. Language other than English was not an exclusion criterion. Cases of liver injury or HCC from causes not closely related to occupational or environmental exposures to chemicals were not included.

\subsection{VCM and Polyvinyl Chloride}

VCM is a chlorinated organic compound (Figure 1); at room temperature and pressure, VCM is a typically sweet smelling colorless gas insoluble in water. It is mainly used in the production of the polymer polyvinyl chloride (PVC) (18). VCM is rapidly absorbed after respiratory exposure and is primarily metabolized by the liver (19). The metabolic pathway for the elimination of VCM generates intermediate metabolites that can also form mutagenic DNA adducts (20). Moreover, the production of VCM and PVC involves the use of various chemicals, some of which are carcinogenic (i.e. ethylene dichloride) (21). VCM is extensively used as a refrigerant in the plastic-manufacturing industry and as an intermediate in organic synthesis (22). Before the implementation of environmental controls, VCM exposure levels were high, measuring up to $13000 \mathrm{ppm}$ (23). Nowadays, in developed countries where strict controls have been instituted, the levels of occupational exposure to VCM are usually less than 1 ppm (24). Evidence from a wide range of experimental and epidemiological studies has shown the carcinogenicity of VCM in animal models and humans (20). Therefore, VCM has been classified as a group I carcinogen by the IARC $(18,25)$. There is considerable evidence about the association between occupational exposure to VCM and liver cancer (15), as well as tumors of the brain (26), lungs (27), and hemolymphopoietic system (28). VCM is known to cause ASL, but it can also exert other toxic effects on the liver, including cirrhosis and HCC (29). VCM exerts a directly toxic effect on the liver (19), and it may also cooperate with other risk factors to cause liver injury (29, 30). VCM causes damage mainly at the sinusoidal level, but hepatocytes may also be involved $(12,31)$. Maroni et al. (32) have reported that the findings of liver ultrasonog-

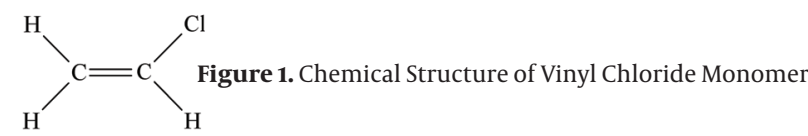


raphy in VCM-exposed workers showed abnormalities such as hepatomegaly, steatosis, and periportal fibrosis, with a frequency of occurrence higher than the expected range in the general population. Furthermore, a high prevalence of Kras2 mutations (33) and a characteristic p53 mutation pattern (34) have been observed in VCMexposed workers with HCC. In 2003, Boffetta et al. (15) conducted a meta-analysis on studies of occupational exposure to VCM and its relationship with cancer mortality. The meta-analysis included most of the previously studied workers populations in the United States, Europe, and Asia. Apart from the known risk of ASL, workers exposed to VCM were found to have a high risk of HCC. Many investigations have analyzed a cohort of Italian blue-collar workers in a VCM petrochemical plant in Porto Marghera (Venice, Italy) (35-37). Using a group of workers with low (or null) exposure to VCM as an internal reference, Gennaro et al. (35) reanalyzed the cohort of blue-collar work- ers during the follow-up period from 1972 to 1999. Mortality from liver cancer, including ASL and HCC, was high in autoclave workers. In conclusion, the epidemiological and experimental studies have reported sufficient data supporting an association between inhalation exposure to VCM and HCC (21) (Table 1).

\subsection{Organic Solvents}

Occupational exposure to various types of organic solvents, such as chlorinated, aromatic, aliphatic, or alicyclic hydrocarbons, is common in many industrial sectors. High risk of mortality from cancer of the liver and biliary passage was found in a meta-analysis of cohort studies among workers generally exposed to organic solvents (38). However, few studies have been conducted on the association between the exposure to individual solvents and the risk of developing liver cancer, with

Table 1. Brief Summary of the Latest International Agency for Research on Cancer (IARC) Evaluation Reports on the Carcinogenicity of Vinyl Chloride, Arsenic, Trichloroethylene, Perchloroethylene, Polychlorinated Biphenyls, and 1,1,1-Trichloro-2,2-Bis(p-chlorophenyl)Ethane (DDT)

\begin{tabular}{llll} 
& Year of Publication & Group Assigned by IARC & $\begin{array}{l}\text { Summary of IARC Evaluation on Overall and } \\
\text { Liver Carcinogenicity }\end{array}$ \\
\hline Vinyl chloride & 2008 & $\begin{array}{l}\text { Group 1 } \\
\text { (carcinogenic to humans) }\end{array}$ & $\begin{array}{l}\text { There is sufficient evidence for the carcinogenicity of } \\
\text { vinyl chloride because it has been found to induce } \\
\text { angiosarcomas of the liver and hepatocellular carci- } \\
\text { nomas in both humans and experimental animals (21). }\end{array}$
\end{tabular}

\begin{tabular}{lll}
\hline Arsenic & 2004 & $\begin{array}{l}\text { Group 1 } \\
\text { (carcinogenic to humans) }\end{array}$ \\
& \\
\hline $\begin{array}{l}\text { Trichloroethyl- } \\
\text { ene }\end{array}$ & 1995 & $\begin{array}{l}\text { Group 2A } \\
\text { (probably carcinogenic to humans) }\end{array}$ \\
\hline
\end{tabular}

\begin{tabular}{|c|c|c|}
\hline $\begin{array}{l}\text { Perchloroethy- } \\
\text { lene }\end{array}$ & 1995 & $\begin{array}{l}\text { Group } 2 \mathrm{~A} \\
\text { (probably carcinogenic to humans) }\end{array}$ \\
\hline $\begin{array}{l}\text { Polychlorinated } \\
\text { biphenyls }\end{array}$ & 1987 & $\begin{array}{l}\text { Group } 2 \mathrm{~A} \\
\text { (probably carcinogenic to humans) }\end{array}$ \\
\hline
\end{tabular}

$\begin{array}{ll}1991 & \begin{array}{l}\text { Group 2B } \\ \text { (possibly carcinogenic to humans) }\end{array}\end{array}$

There is sufficient evidence in humans that arsenic in drinking water causes cancers of the urinary bladder, lung, and skin; however, the interpretation of the findings on liver cancer mortality has several methodological limitations. Moreover, the studies on inorganic arsenic provide limited evidence for carcinogenicity in experimental animals (102).

Evidence from several epidemiological studies suggests that trichloroethylene may enhance the risks for non-Hodgkin's lymphoma and cancers of the liver and biliary tract. Trichloroethylene can also induce liver tumors in rodents through peroxisome proliferation and other mechanisms (40).

There is consistent evidence for positive associations between exposure to tetrachloroethylene and the risks for non-Hodgkin's lymphoma and esophageal and cervical cancer. Although tetrachloroethylene is known to induce hepatocellular carcinomas in experimental animals, evidence of liver tumor induction in humans is inconsistent (40).

Evidence for carcinogenicity in humans is limited. An increased risk from hepatobiliary cancer has been found in different studies, which were biased. On the other hand, evidence for carcinogenicity in animals is sufficient. Administration of certain polychlorinated biphenyls produced benign and malignant liver neoplasms in mice and rats (25).

There is inadequate evidence for the carcinogenicity of DDT in humans. Evidence for the carcinogenicity of DDT in experimental animals is sufficient, particularly for liver tumors (121).

\footnotetext{
a After the publication of the last IARC monographs, there has been more evidence regarding the carcinogenic effect of these chemicals on the liver.
} 
the exception of trichloroethylene (TCE) and perchloroethylene (PCE). TCE, a nonflammable colorless liquid, is an important environmental and industrial pollutant. During the past decades, it has been widely used as an industrial solvent and degreasing agent (39). Because TCE is a common contaminant of groundwater and air, its potential in adversely affecting human health is being studied and debated; however, its worldwide industrial use has decreased over time. Occupations involving TCE exposure include aircraft/aerospace maintenance or manufacture and other industries, including metal degreasing, shoe manufacturing, painting, dry cleaning, electronics, printing, and chemical industries (40, 41). Although TCE exposure has been associated with a wide array of adverse health effects, its toxicity mainly affects the kidney and liver (42). The possible carcinogenicity of TCE remains a controversy. Experimental studies have shown high risks of kidney, liver, lung, and hematopoietic neoplasms among TCE-exposed animals from different species (43). However, discordance in the results of the studies and species-specific differences in TCE metabolism have limited the extrapolation of these findings to human carcinogenesis $(44,45)$. TCE exposure, for instance, causes HCC in mice but not in rats (46). The precise modes of action (MOAs) by which TCE exposure causes liver tumorigenesis are presently unknown. However, such mechanisms might include: peroxisome proliferation induction; oxidative stress; alterations in cell replication, selection, or apoptosis as a result of cellsignaling; and DNA mutagenic effects (47). Laboratory studies indicate that TCE is not the only chemical responsible for the occurrence of tumors in TCE-treated mice; its 2 metabolites, dichloroacetic acid and trichloroacetic acid, also cause such tumors, probably via different MOAs (49). A slightly increased risk of developing liver cancer has been found among workers exposed to TCE, but inconsistencies in findings across the study populations and some methodological limitations make the currently available epidemiologic data insufficient in supporting a causal relationship between occupational exposure to TCE and HCC in humans $(16,39,41,43)$. (Table 1)

PCE, also known as tetrachloroethylene, is an important chemical primarily used in the dry-cleaning and textile industries and for metal degreasing (48). Many studies have provided clear evidence that both acute and chronic exposure to PCE can cause gastrointestinal disturbances and numerous adverse effects on the central nervous system, kidney, liver, and upper respiratory tract (49-53). In the dry-cleaning industry, the highest exposure occurs during the operation of the machinery, primarily via inhalation and dermal contact (54). An augmented risk of liver cancer has been reported among workers and experimental animals potentially exposed to PCE (55-57); however, the presently available data on this association is inconclusive. IARC has defined PCE as probably carcinogenic to humans (group 2A) working in the dry-cleaning industry (40) (Table 1). The findings of a hospital-based case-control study conducted in northern Italy during 1997-1999 suggest that occupational risk factors for exposure to xylene and toluene play a role in the development of liver cancer (58).

\subsection{1,1,1-Trichloro-2,2-bis(p-chlorophenyl)Ethane (DDT) and Other Pesticides}

Many epidemiological studies have suggested that pesticides play a role in HCC development among people employed in the agriculture industry and who routinely use chemicals to control insects, weeds, rodents, and fungal infections of crops and livestock $(14,17,59,60)$. Moreover, various pesticides such as dieldrin (61), lindane (24), chlordane (62), heptachlor (62), and pyrethrins (63) are established carcinogens in animal models, because the administration of high doses of these pesticides clearly induces liver tumors in some species. However, few investigations have aimed to verify the association between individual pesticides and the risk of liver cancer, except for DDT (Figure 2). DDT is a potent insecticide that was largely used for agricultural and public health purposes from the 1940s to the 1970s; however, concerns about its toxic effects and environmental persistence led many developed countries to ban its use (64). However, DDT is still widely used in Asia and Africa for disease-vector and termite control and as an agricultural insecticide (65). Furthermore, the recommendations and guidelines of the World Health Organization allow the use of DDT to control disease vectors, until suitable alternatives are available (66). The general population is exposed to DDT, primarily through food ingestion, whereas occupational exposures are mainly by inhalation and dermal contact $(67,68)$. The compound is preferentially stored in the adipose tissue, but the uptake of DDT by fat is slow. Thus, DDT is mostly distributed to other tissues following exposure to a single large dose and to adipose tissue following many small doses. Despite the affinity of DDT for adipose tissue, most of the DDT-related compounds in blood are bound to proteins (69). DDT and its metabolite, 1,1-dichloro-2,2-bis( $p$-chlorophenyl)ethylene (DDE) have been shown to produce numerous adverse health effects in humans, including neurological, carcinogenic, reproductive, and developmental disorders (67). On the basis of the evidence obtained from animal studies, DDT has been classified as a possible carcinogen (group 2B) by IARC (70) (Table 1) and as a reasonably anticipated human carcinogen by the US National Toxicology Program (71). Similar to many other chlorinated compounds, DDT produces liver cancer in laboratory animals (61, 69). Humans exposed to DDT at work have been reported to have a high risk of liver cancer $(59,72)$. Furthermore, an ecological study (73) has found a statistically significant correlation between the amount of DDE in adipose tis- 
sue and liver cancer mortality rates in white men but not in white women or black men. In a nested case-control study (74), the risk of liver cancer was higher in Chinese men with high blood levels of DDT than those with low levels of DDT. Some epidemiological studies on individuals exposed to DDT have suggested that DDT is hepatocarcinogenic in humans; however, the interpretation of the currently available data is difficult because of the lack of association found among other studies and methodological limitations $(67,74-77)$.

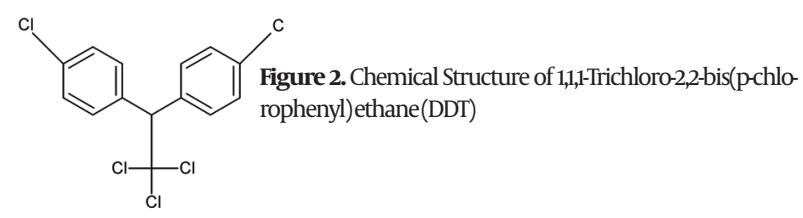

\subsection{Polychlorinated Biphenyls}

Polychlorinated biphenyls (PCBs) are synthetic chlorinated aromatic hydrocarbons, which are considered persistent organic pollutants. Generally, all PCBs have a biphenyl molecule ( 2 attached benzene rings) with a minimum of 1 (but no more than 10) chlorine atoms (Figure 3). The chemical formula for PCBs is $\mathrm{C}_{12} \mathrm{H}_{10-\mathrm{x}} \mathrm{Cl}_{\mathrm{x}}$, and 209 different $\mathrm{PCB}$ congeners are theoretically possible, depending upon the placement of chlorine atoms; however, only about 130 have been found in commercial PCB mixtures (78). PCBs were widely produced commercially in the USA from 1929 to 1977 and used as electrical insulating, heat exchange, and lubricating fluids because of their high stability, dielectric properties, resistance to oxidation, and incombustibility. PCBs were also blended with other chemicals, such as plasticizers and fire retardants, and used in a variety of products including caulks, adhesives, plastics, and carbonless copy paper. The production of PCBs was highest in the 1970s and had steadily declined thereafter because many countries worldwide have banned the use of PCBs or limited their production $(79,80)$. Nevertheless, these compounds are still in use and are human health hazards and pose a risk of potential occupational exposure, particularly to people engaged in the maintenance of electrical equipment (78, 81). Most PCBs do not exert particularly acute toxicity, but their persistence, lipophilicity, and propensity to storage in the adipose tissue raise concern over their long-term effects. In animals and humans, chronic exposure to PCBs produces a variety of effects, including reduced body weight, chloracne, edema, liver hypertrophy, porphyria, estrogenic activity, immunosuppression, and neurotoxicity $(79,82)$. IARC has classified PCBs as a probable human carcinogens (group 2A) on the basis of the evidence of carcinogenicity observed in animals; however, limited evidence has been obtained from human studies (25) (Table 1). Many animal studies conducted by the US National
Toxicology Program and others have shown that PCBs play a role in the development of liver disease (83-87). These studies have shown that the liver is the principal target organ for these compounds. Occurrence of benign (toxic hepatopathy, including steatosis) and malignant (HCC and cholangiocarcinoma) liver lesions depends on the dose of the carcinogen. Although laboratory data clearly indicate that PCBs promote activity in the liver and induce preneoplastic lesions and HCCs in animals in a dose- and time-dependent manner, their precise mechanism of action is not known. Many MOAs have been proposed, including direct effects on signal transduction pathways, induction of oxidative stress, effects on vitamin A metabolism, and effects on intercellular communication (88). PCBs are also associated with elevated levels of human alanine transaminase and increased hepatic gene expressions of genes involved in apoptosis, inflammation, and oxidative stress (86). In contrast to the findings of animal studies, data on PCBs in liver diseases in humans are lacking. During a 24-year follow-up after the "Yucheng" incident in Taiwan, where cooking oil was contaminated by PCBs, people of Yechung exposed to high amounts of PCBs showed high mortality from chronic liver disease and cirrhosis $(89,90)$. While other epidemiological studies have reported an increased mortality from HCC and other cancers among subjects heavily exposed to PCBs (91), Yucheng individuals mortality rates from all malignant neoplasms and liver cancer was not different from those of the general population (90). Moreover, epidemiological evidence shows a link between occupational exposure to PCBs and the risk of HCC. Several studies have investigated the health effects of PCBs among cohorts of electrical capacitor and transformer manufacturing workers and have found a relationship between cumulative exposure to PCBs and liver cancer mortality; however, the hepatocarcinogenesis of PCBs in humans is still controversial (92-95).

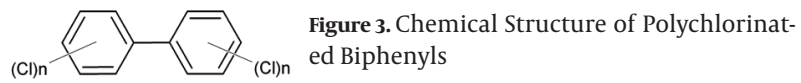

\subsection{Arsenic}

Arsenic (As), a natural metalloid element, is considered one of the most significant health hazards in the environment. Groundwater contamination with inorganic As is the primary route of exposure. Exposure to As also results from consumption of contaminated food, contact with contaminated soil, or inhalation of As at work (96-99). Furthermore, arsenicals have been increasingly used in the medical treatment of some types of neoplasms (100). Occupational exposure to As can occur in a number of work settings such as As pesticide manufacturing and use, As refining, glassware factories, semiconductor fabrication, extractive mining, and copper smelt- 
ing (99). In occupationally exposed subjects, urine and blood samples can be used to estimate the individual doses of ongoing exposure, whereas hair and nail samples can be used to determine the average exposure over a long duration of time (98). Data from epidemiological studies suggest that As exposure is associated with a large number of adverse health effects in various organs and tissue systems, including the cardiovascular, dermal, endocrine, neurological, reproductive, respiratory, hepatic, hematological, renal, and gastrointestinal systems (101). Moreover, after reviewing experimental and epidemiological data, IARC has classified As as a group 1 carcinogen (Table 1). Chronic exposure to As is associated with cancers of the skin, lung, urinary bladder, and possibly liver, kidney, and prostate in humans $(102,103)$. When considering the carcinogenicity of As, it is important to distinguish between exposure to inorganic and organic forms of As, because only exposure to inorganic As compounds has been associated with cancer (104). Organic As is most abundant in food, particularly seafood, whereas inorganic As compounds are found mainly in drinking water (105). Chronic As exposure causes preneoplastic lesions and liver dysfunctions such as abnormal liver function, hepatomegaly, hepatoportal sclerosis, liver fibrosis, cirrhosis, and ASL (106). While drafting the last IARC monograph, the evidence for As as a liver carcinogen in experimental models was considered limited (102). However, recent laboratory data have shown that the liver is a major target for inorganic As carcinogenesis in rodents and cell model systems (107-111). The exact MOAs of As carcinogenicity, including hepatocarcinogenesis, are not clearly defined, and various potential mechanisms have been postulated (107). These mechanisms include genetic and epigenetic mechanisms such as oxidative DNA damage (112), acquired tolerance to apoptosis, (113) enhanced cell proliferation (114), abnormal DNA methylation (108), genomic instability (115), and aberrant estrogen signaling (116). An increased risk of HCC and ASL in association with environmental exposures to As has also been extensively reported in epidemiological studies and case reports. Many of these investigations have been performed among Asiatic cohorts of people consuming water with high levels of As contamination (117-120).

\section{Results}

Accumulating laboratory findings have clearly indicated that the liver is an important target of carcinogenesis caused by exposure to various chemicals. Compared to experimental studies, epidemiological studies provide very limited evidence on occupational risk factors for HCC. Nevertheless, according to the IARC working group, such association is particularly clear with regard to VCM. Indeed, the incidence of HCC, ASL and liver cirrhosis significantly increases with cumulative occupational exposure to VCM. Moreover, we found some case reports and epidemiological data showing a moderately increased risk of HCC development in people exposed to, organic solvents, pesticides, PCBs, and As. However, the interpretation of these findings is limited by the small number of studies available, questionable accuracy of the diagnosis of liver cancer due to the lack of histological or other definitive clinical data in discriminating HCC from ASL and/or secondary neoplasms, and potential confounding or modifying factors such as chronic hepatitis virus infection and alcohol consumption. Further relevant investigations are required for clarifying the actual contribution of occupational exposure to specific chemicals in HCC development.

\section{Conclusions}

Regardless HCC, prolonged exposure to toxic substances may result in the setting of liver disease. Therefore, it would be reasonable that workers heavily exposed to hepatotoxic chemicals undergo health surveillance, especially in the presence of other established risk factors. The monitoring of liver function should be particularly aimed in detecting any alteration in transaminases, gamma-glutamyltransferase, alkaline phosphatase, and bilirubin levels. In case of marked alterations of these indices, even in the absence of cirrhosis, alpha-fetoprotein levels measurement and hepatic ultrasound examination should be implemented. Such surveillance may well facilitate the early detection of toxic liver diseases (including HCC) in workers exposed to chemcals.

\section{Acknowledgments}

The authors thank Alessia Trovato for helping with editing the article and revising the language.

\section{Financial Disclosure}

Authors declared no conflicts of interest.

\section{Funding/Support}

None declared.

\section{References}

1. Landrigan PJ, Espina C, Neira M. Global prevention of environmental and occupational cancer. Environ Health Perspect. 2011;119(7):A280-1.

2. Barbieri PG. [To-day exposure to occupational carcinogens and their effects. The experience of the rubber industry, iron metallurgy, asphalt work and aviculture]. Epidemiol Prev. 2009;33(4-5 Suppl 2):94-105.

3. Blair A, Marrett L, Beane Freeman L. Occupational cancer in developed countries. Environ Health. 2011;10(Suppl 1):S9.

4. Malaguarnera G, Giordano M, Paladina I, Berretta M, Cappellani A, Malaguarnera M. Serum markers of hepatocellular carcinoma. Dig Dis Sci. 2010;55(10):2744-55.

5. Malaguarnera G, Giordano M, Paladina I, Rando A, Uccello M, Basile F, et al. Markers of bile duct tumors. World J Gastrointest Oncol. 2011;3(4):49-59.

6. Parkin DM, Bray F, Ferlay J, Pisani P. Global cancer statistics, 2002. CA Cancer J Clin. 2005;55(2):74-108.

7. Chen CJ, Yu MW, Liaw YF. Epidemiological characteristics and 
risk factors of hepatocellular carcinoma.J Gastroenterol Hepatol. 1997;12(9-10):S294-308.

8. El-Serag HB, Rudolph KL. Hepatocellular carcinoma: epidemiology and molecular carcinogenesis. Gastroenterology. 2007;132(7):2557-76

9. Abe H, Yoshizawa K, Kitahara T, Aizawa R, Matsuoka M, Aizawa Y. Etiology of non-B non-C hepatocellular carcinoma in the eastern district of Tokyo.J Gastroenterol. 2008;43(12):967-74.

10. Sanyal AJ, Yoon SK, Lencioni R. The etiology of hepatocellular carcinoma and consequences for treatment. Oncologist. 2010;15(Suppl 4):14-22.

11. Tanaka K, Tsuji I, Wakai K, Nagata C, Mizoue T, Inoue M, et al. Cigarette smoking and liver cancer risk: an evaluation based on a systematic review of epidemiologic evidence among Japanese. Jpn J Clin Oncol. 2006;36(7):445-56.

12. Sherman M. Vinyl chloride and the liver. $J$ Hepatol. 2009:51(6):1074-81.

13. Huff J, Cirvello J, Haseman J, Bucher J. Chemicals associated with site-specific neoplasia in 1394 long-term carcinogenesis experiments in laboratory rodents. Environ Health Perspect.1991;93:24770.

14. Anwar WA, Khaled HM, Amra HA, El-Nezami H, Loffredo CA. Changing pattern of hepatocellular carcinoma (HCC) and its risk factors in Egypt: possibilities for prevention. Mutat Res. 2008;659(1-2):176-84

15. Boffetta P, Matisane L, Mundt KA, Dell LD. Meta-analysis of studies of occupational exposure to vinyl chloride in relation to cancer mortality. Scand J Work Environ Health. 2003;29(3):220-9.

16. Lindbohm ML, Sallmen M, Kyyronen P, Kauppinen T, Pukkala E. Risk of liver cancer and exposure to organic solvents and gasoline vapors among Finnish workers. Int $J$ Cancer. 2009;124(12):2954-9.

17. Soliman AS, Hung CW, Tsodikov A, Seifeldin IA, Ramadan M, AlGamal D, et al. Epidemiologic risk factors of hepatocellular carcinoma in a rural region of Egypt. Hepatol Int. 2010;4(4):681-90.

18. International Agency for Research on Cancer. IARC monographs on the evaluation of carcinogenic risks to humans.13-butadiene, ethylene oxide and vinyl halides (vinyl fluoride, vinyl chloride and vinyl bromide). Lyon: IARC Press; 2008.

19. Bolt HM. Vinyl chloride-a classical industrial toxicant of new interest. Crit Rev Toxicol. 2005;35(4):307-23.

20. Dogliotti E. Molecular mechanisms of carcinogenesis by vinyl chloride. Ann Ist Super Sanita. 2006;42(2):163-9.

21. Fred C, Törnqvist M, Granath F. Evaluation of cancer tests of 1 , 3-butadiene using internal dose, genotoxic potency, and a multiplicative risk model. Cancer Res. 2008;68(19):8014.

22. World Health Organization. Environmental Health Criteria 215: Vinyl Chloride. Geneva: WHO. Available from: http://www.who.int/ ipcs/publications/ehc/ehc_215/en/index.html

23. Barnes AW. Vinyl chloride and the production of PVC. Proc R Soc Med.1976;69(4):277-81.

24. Dobecki M, Romanowicz B. [Occupational exposure to toxic substances during the production of vinyl chloride and chlorinated organic solvents]. Med Pr. 1993;44(2):99-102.

25. International Agency for Research on Cancer. IARC Monograph on the Evaluation of Carcinogenic Risks to Humans. Overall Evaluations of Carcinogenicity: An Updating of IARC Monographs Volumes 1 to 42 . Lyon; 1987.

26. Lewis R, Rempala G, Dell LD, Mundt KA. Vinyl chloride and liver and brain cancer at a polymer production plant in Louisville, Kentucky.J Occup Environ Med. 2003;45(5):533-7.

27. Mastrangelo G, Fedeli U, Fadda E, Milan G, Turato A, Pavanello S. Lung cancer risk in workers exposed to poly(vinyl chloride) dust: a nested case-referent study. Occup Environ Med. 2003;60(6):423-

28. Hsieh HI, Chen PC, Wong RH, Du CL, Chang YY, Wang JD, et al. Mortality from liver cancer and leukaemia among polyvinyl chloride workers in Taiwan: an updated study. Occup Environ Med. 2011;68(2):120-5.

29. Mastrangelo G, Fedeli U, Fadda E, Valentini F, Agnesi R, Magarotto G, et al. Increased risk of hepatocellular carcinoma and liver cirrhosis in vinyl chloride workers: synergistic effect of oc- cupational exposure with alcohol intake. Environ Health Perspect. 2004;112(11):1188-92.

30. Hsieh HI, Wang JD, Chen PC, Cheng TJ. Synergistic effect of hepatitis virus infection and occupational exposures to vinyl chloride monomer and ethylene dichloride on serum aminotransferase activity. Occup Environ Med. 2003;60(10):774-8.

31. Popper H, Maltoni C, Selikoff IJ. Vinyl chloride-induced hepatic lesions in man and rodents. A comparison. Liver. 1981;1(1):7-20.

32. Maroni M, Mocci F, Visentin S, Preti G, Fanetti AC. Periportal fibrosis and other liver ultrasonography findings in vinyl chloride workers. Occup Environ Med. 2003;60(1):60-5.

33. Weihrauch M, Benick $M$, Lehner $G$, Wittekind $M$, Bader $M$, Wrbitzk R, et al. High prevalence of K-ras-2 mutations in hepatocellular carcinomas in workers exposed to vinyl chloride. Int Arch Occup Environ Health. 2001;74(6):405-10.

34. Weihrauch M, Lehnert G, Kockerling F, Wittekind C, Tannapfel A. p53 mutation pattern in hepatocellular carcinoma in workers exposed to vinyl chloride. Cancer. 2000;88(5):1030-6.

35. Gennaro V, Ceppi M, Crosignani P, Montanaro F. Reanalysis of updated mortality among vinyl and polyvinyl chloride workers: Confirmation of historical evidence and new findings. BMC Public Health. 2008;8:21.

36. Gennaro V, Ceppi M, Montanaro F. [Reanalysis of mortality in a petrochemical plant producing vinyl chloride and polyvinyl chloride]. Epidemiol Prev. 2003;27(4):221-5.

37. Pirastu R, Baccini M, Biggeri A, Comba P. [Epidemiologic study of workers exposed to vinyl chloride in Porto Marghera: mortality update]. Epidemiol Prev. 2003;27(3):161-72.

38. Chen R, Seaton A. A meta-analysis of mortality among workers exposed to organic solvents. Occup Med (Lond). 1996;46(5):33744.

39. Weiss NS. Cancer in relation to occupational exposure to trichloroethylene. Occup Environ Med. 1996;53(1):1-5.

40. International Agency for Research on Cancer. Dry cleaning, some chlorinated solvents and other industrial chemicals. Lyon, France, 7-14 February 1995. IARC Monogr Eval Carcinog Risks Hum. 1995;63:33-477.

41. Alexander DD, Kelsh MA, Mink PJ, Mandel JH, Basu R, Weingart M. A meta-analysis of occupational trichloroethylene exposure and liver cancer. Int Arch Occup Environ Health. 2007;81(2):127-43.

42. Caldwell JC, Keshava N. Key issues in the modes of action and effects of trichloroethylene metabolites for liver and kidney tumorigenesis. Environ Health Perspect. 2006;114(9):1457-63.

43. Scott CS, Chiu WA. Trichloroethylene cancer epidemiology: a consideration of select issues. Environ Health Perspect. 2006;114(9):1471-8.

44. Henschler D, Elsasser H, Romen W, Eder E. Carcinogenicity study of trichloroethylene, with and without epoxide stabilizers, in mice.J Cancer Res Clin Oncol. 1984;107(3):149-56.

45. Henschler D, Romen W, Elsasser HM, Reichert D, Eder E, Radwan Z. Carcinogenicity study of trichloroethylene by longterm inhalation in three animal species. Arch Toxicol. 1980;43 (4):237-48.

46. NTP Carcinogenesis Studies of Trichloroethylene (Without Epichlorohydrin) (CAS No. 79-01-6) in F344/N Rats and B6C3F1 Mice (Gavage Studies). Natl Toxicol Program Tech Rep Ser.1990;243:1-174.

47. Chiu WA, Caldwell JC, Keshava N, Scott CS. Key scientific issues in the health risk assessment of trichloroethylene. Environ Health Perspect. 2006;114(9):1445-9.

48. Gold LS, De Roos AJ, Waters M, Stewart P. Systematic literature review of uses and levels of occupational exposure to tetrachloroethylene. J Occup Environ Hyg. 2008;5(12):807-39.

49. Benignus VA, Boyes WK, Geller AM, Bushnell PJ. Long-term perchloroethylene exposure: a meta-analysis of neurobehavioral deficits in occupationally and residentially exposed groups. $J$ Toxicol Environ Health A. 2009;72(13):824-31.

50. Garnier R, Bedouin J, Pepin G, Gaillard Y. Coin-operated dry cleaning machines may be responsible for acute tetrachloroethylene poisoning: report of 26 cases including one death.J Toxicol Clin Toxicol.1996;34(2):191-7.

51. Lash LH, Parker JC. Hepatic and renal toxicities associated with perchloroethylene. Pharmacol Rev. 2001;53(2):177-208.

52. Shen C, Zhao CY, Liu F, Wang YD, Wang W. Acute liver failure as- 
sociated with occupational exposure to tetrachloroethylene. Korean Med Sci. 2011;26(1):138-42.

53. Agency for Toxic Substances and Disease Registry. Toxicological Profile for Tetrachloroethylene. Atlanta (GA): U.S. Department of Health and Human Services Public Health Service Agency for Toxic Substances and Disease Registry; Sep 1997.

54. Mundt KA, Birk T, Burch MT. Critical review of the epidemiological literature on occupational exposure to perchloroethylene and cancer. Int Arch Occup Environ Health. 2003;76(7):473-91.

55. NTP Toxicology and Carcinogenesis Studies of Tetrachloroethylene (Perchloroethylene) (CAS No. 127-18-4) in F344/N Rats and B6C3F1 Mice (Inhalation Studies). Natl Toxicol Program Tech Rep Ser. 1986;311:1-197.

56. Lynge E, Thygesen L. Primary liver cancer among women in laundry and dry-cleaning work in Denmark. Scand J Work Environ Health. 1990;16(2):108-12.

57. Stemhagen A, Slade J, Altman R, Bill J. Occupational risk factors and liver cancer. A retrospective case-control study of primary liver cancer in New Jersey. Am J Epidemiol.1983;117(4):443-54.

58. Porru S, Placidi D, Carta A, Gelatti U, Ribero ML, Tagger A, et al. Primary liver cancer and occupation in men: a case-control study in a high-incidence area in Northern Italy. Int $J$ Cancer. 2001;94(6):878-83.

59. Chrisman Jde R, Koifman S, de Novaes Sarcinelli P, Moreira JC, Koifman RJ, Meyer A. Pesticide sales and adult male cancer mortality in Brazil. Int J Hyg Environ Health. 2009;212(3):310-21.

60. Cordier S, Le TB, Verger P, Bard D, Le CD, Larouze B, et al. Viral infections and chemical exposures as risk factors for hepatocellular carcinoma in Vietnam. Int J Cancer. 1993;55(2):196-201.

61. Lipsky MM, Trump BF, Hinton DE. Histogenesis of dieldrin and DDT-induced hepatocellular carcinoma in Balb/c mice.J Environ Pathol Toxicol Oncol.1989;9(1):79-93.

62. Some thyrotropic agents. IARC Monogr Eval Carcinog Risks Hum. 2001;79:i-iv, 1-725.

63. Osimitz TG, Lake BG. Mode-of-action analysis for induction of rat liver tumors by pyrethrins: relevance to human cancer risk. Crit Rev Toxicol.2009;39(6):501-11.

64. Agency for Toxic Substances and Disease Registry. Toxicological Profile for DDT, DDE, and DDD. Atlanta (GA): U.S. Department fo Health and Human Services, Public Health Service, Agency for Toxic Substances and Disease Registry; Sep 2002.

65. van den Berg H. Global status of DDT and its alternatives for use in vector control to prevent disease. Cien Saude Colet. 2011;16(2):575-90.

66. World Health Organization. The use of DDT in malaria vector control: WHO position statement. Geneva, Switzerland: WHO; 2007.

67. Rogan WJ, Chen A. Health risks and benefits of bis(4-chlorophenyl)1,1,1-trichloroethane (DDT). Lancet. 2005;366(9487):763-73.

68. Smith AG. DDT and its analogs. In: Krieger R, editor. Handbook of pesticide toxicology. 2nd ed. San Diego (CA): Academic Press; 2001 p. 1305-55.

69. World Health Organization. DDT and its derivatives. Environmental health criteria 9. Geneva, Switzerland: WHO. 1979. Available from: http://apps.who.int/iris/handle/10665/39562.

70. International Agency for Research on Cancer, Working Group on the Evaluation of Carcinogenic Risks to Humans. IARC monographs on the evaluation of carcinogenic risks to humans: Occupational exposures in insecticide application, and some pesticides. Lyon, France: International Agency for Research on Cancer; 1991.

71. National Toxicology Program (NTP), Report on Carcinogens. 12th ed: Research Triangle Park (NC): U.S. Department of Health and Human Services, Public Health Service, National Toxicology Program; 2011.

72. Figa-Talamanca I, Mearelli I, Valente P. Mortality in a cohor of pesticide applicators in an urban setting. Int $J$ Epidemiol. 1993;22(4):674-6.

73. Cocco P, Kazerouni N, Zahm SH. Cancer mortality and environmental exposure to DDE in the United States. Environ Health Perspect. 2000;108(1):1-4.

74. McGlynn KA, Abnet CC, Zhang M, Sun XD, Fan JH, O'Brien TR, et al. Serum concentrations of 1,1,1-trichloro-2,2-bis(p-chlorophe- nyl)ethane (DDT) and 1,1-dichloro-2,2-bis(p-chlorophenyl)ethylene (DDE) and risk of primary liver cancer. J Natl Cancer Inst. 2006;98(14):1005-10.

75. Cocco P, Fadda D, Billai B, D'Atri M, Melis M, Blair A. Cancer mortality among men occupationally exposed to dichlorodiphenyltrichloroethane. Cancer Res. 2005;65(20):9588-94.

76. Hardell L, Bengtsson NO, Jonsson U, Eriksson S, Larsson LG. Aetiological aspects on primary liver cancer with special regard to alcohol, organic solvents and acute intermittent porphyria--an epidemiological investigation. BrJ Cancer. 1984;50(3):389-97.

77. Laws ER, Jr., Maddrey WC, Curley A, Burse VW. Long-term occupational exposure to DDT. Arch Environ Health. 1973;27(5):318-21.

78. Crinnion WJ. Polychlorinated biphenyls: persistent pollutants with immunological, neurological, and endocrinological consequences. Altern Med Rev. 2011;16(1):5-13.

79. Robertson LW, Hansen LG. PCBs: recent advances in environmenta toxicology and health effects. Lexington (KY): University Press of Kentucky; 2001

80. World Health Organization (WHO). Polychlorinated biphenyls and terphenyls. Environmental health criteria 2. Geneva, Switzerland: WHO; 1976.

81. Erickson MD, Kaley RG, 2nd. Applications of polychlorinated biphenyls. Environ Sci Pollut Res Int. 2011;18(2):135-51.

82. Carpenter DO. Polychlorinated biphenyls (PCBs): routes of exposure and effects on human health. Rev Environ Health. 2006;21(1):1-23.

83. NTP technical report on the toxicology and carcinogenesis studies of 2,2',4,4',5,5'-hexachlorobiphenyl (PCB 153) (CAS No. 35065 27-1) in female Harlan Sprague-Dawley rats (Gavage studies). Natl Toxicol Program Tech Rep Ser. 2006;(529):4-168.

84. Toxicology and carcinogenesis studies of a binary mixture of 3,3',4,4',5-pentachlorobiphenyl (PCB 126) (Cas No. 57465-28-8) and 2,2',4,4',5,5'-hexachlorobiphenyl (PCB 153) (CAS No. 3506527-1) in female Harlan Sprague-Dawley rats (gavage studies). Natl Toxicol Program Tech Rep Ser. 2006;(530):1-258.

85. Toxicology and carcinogenesis studies of a binary mixture of 3,3',4,4',5-pentachlorobiphenyl (PCB 126) (Cas No. 57465-28-8) and 2,3',4,4',5-pentachlorobiphenyl (PCB 118) (Cas No. 31508-006 ) in female Harlan Sprague-Dawley rats (gavage studies). Natl Toxicol Program Tech Rep Ser. 2006;(531):1-218.

86. Hennig B, Reiterer G, Toborek M, Matveev SV, Daugherty A, Smart E, et al. Dietary fat interacts with PCBs to induce changes in lipid metabolism in mice deficient in low-density lipoprotein receptor. Environ Health Perspect. 2005;113(1):83-7.

87. Norback DH, Weltman RH. Polychlorinated biphenyl induction of hepatocellular carcinoma in the Sprague-Dawley rat. Environ Health Perspect. 1985;60:97-105.

88. Glauert HP, Robertson LW, Silberhorn EM. PCBs: recent advances in environmental toxicology and health effects. In: Robertson LW, Hansen LG, editors. Lexington (KY): University Press of Kentucky; 2001.

89. Bencko V, Rames J, Ondrusova M, Plesko I, Jurickova L, Trnovec T. Human exposure to polyhalogenated hydrocarbons and incidence of selected malignancies -central European experience. Neoplasma. 2009;56(4):353-7.

90. Tsai PC, Ko YC, Huang W, Liu HS, Guo YL. Increased liver and lupus mortalities in 24-year follow-up of the Taiwanese people highly exposed to polychlorinated biphenyls and dibenzofurans. Sci Total Environ. 2007;374(2-3):216-22.

91. Zhao G, Wang Z, Zhou H, Zhao Q. Burdens of PBBs, PBDEs, and PCBs in tissues of the cancer patients in the e-waste disassembly sites in Zhejiang, China. Sci Total Environ. 2009;407(17):4831-7.

92. Bertazzi PA, Riboldi L, Pesatori A, Radice L, Zocchetti C. Cance mortality of capacitor manufacturing workers. Am J Ind Med. 1987;11(2):165-76.

93. Greenland S, Salvan A, Wegman DH, Hallock MF, Smith TJ. A casecontrol study of cancer mortality at a transformer-assembly facility. Int Arch Occup Environ Health. 1994;66(1):49-54.

94. Mallin K, McCann K, D’Aloisio A, Freels S, Piorkowski J, Dimos J, et al. Cohort mortality study of capacitor manufacturing workers, 1944-2000. J Occup Environ Med. 2004;46(6):565-76.

95. Prince MM, Ruder AM, Hein MJ, Waters MA, Whelan EA, Nilsen N 
et al. Mortality and exposure response among 14,458 electrical capacitor manufacturing workers exposed to polychlorinated biphenyls (PCBs). Environ Health Perspect. 2006;114(10):1508-14.

96. Chen CJ, Chen CW, Wu MM, Kuo TL. Cancer potential in liver, lung, bladder and kidney due to ingested inorganic arsenic in drinking water. BrJ Cancer. 1992;66(5):888-92.

97. Marshall G, Ferreccio C, Yuan Y, Bates MN, Steinmaus C, Selvin $S$, et al. Fifty-year study of lung and bladder cancer mortality in Chile related to arsenic in drinking water. J Natl Cancer Inst. 2007;99(12):920-8.

98. Tapio S, Grosche B. Arsenic in the aetiology of cancer. Mutat Res. 2006;612(3):215-46

99. Xi S, Zheng Q, Zhang Q, Sun G. Metabolic profile and assessment of occupational arsenic exposure in copper- and steel-smelting workers in China. Int Arch Occup Environ Health. 2011;84(3):347-53.

100. Amadori S, Fenaux P, Ludwig H, O’Dwyer M, Sanz M. Use of arsenic trioxide in haematological malignancies: insight into the clinical development of a novel agent. Curr Med Res Opin. 2005;21(3):403-11.

101. Tchounwou PB, Patlolla AK, Centeno JA. Carcinogenic and systemic health effects associated with arsenic exposure--a critical review. Toxicol Pathol. 2003;31(6):575-88.

102. International Agency for Research on Cancer. Some drinkingwater disinfectants and contaminants, including arsenic. IARC Monogr Eval Carcinog Risks Hum. 2004;84:1-477.

103. International Agency for Research on Cancer. IARC Monographs on the Evaluation of Carcinogenic Risks to Humans. Some Metals and Metallic Compounds. Lyon, France: IARC Press; 1980.

104. Pershagen G. The carcinogenicity of arsenic. Environ Health Perspect. 1981;40:93-100.

105. Abernathy CO, Thomas DJ, Calderon RL. Health effects and risk assessment of arsenic. J Nutr. 2003;133(5 Suppl 1):1536S-8S

106. Mazumder DN. Effect of chronic intake of arsenic-contaminated water on liver. Toxicol Appl Pharmacol. 2005;206(2):169-75.

107. Liu J, Waalkes MP. Liver is a target of arsenic carcinogenesis. Toxicol Sci. 2008;105(1):24-32.

108. Reichard JF, Schnekenburger M, Puga A. Long term low-dose arsenic exposure induces loss of DNA methylation. Biochem Biophys Res Commun. 2007;352(1):188-92.

109. Tokar EJ, Benbrahim-Tallaa L, Ward JM, Lunn R, Sams RL, 2nd,
Waalkes MP. Cancer in experimental animals exposed to arsenic and arsenic compounds. Crit Rev Toxicol. 2010;40(10):912-27.

110. Waalkes MP, Liu J, Diwan BA. Transplacental arsenic carcinogenesis in mice. Toxicol Appl Pharmacol. 2007;222(3):271-80.

111. Wanibuchi H, Salim EI, Kinoshita A, Shen J, Wei M, Morimura K, et al. Understanding arsenic carcinogenicity by the use of animal models. Toxicol Appl Pharmacol. 2004;198(3):366-76.

112. Liu J, Kadiiska MB, Liu Y, Lu T, Qu W, Waalkes MP. Stress-related gene expression in mice treated with inorganic arsenicals. Toxicol Sci. 2001;61(2):314-20.

113. Qu W, Bortner CD, Sakurai T, Hobson MJ, Waalkes MP. Acquisition of apoptotic resistance in arsenic-induced malignant transformation: role of the JNK signal transduction pathway. Carcinogenesis. 2002;23(1):151-9.

114. Waalkes MP, Keefer LK, Diwan BA. Induction of proliferative lesions of the uterus, testes, and liver in swiss mice given repeated injections of sodium arsenate: possible estrogenic mode of action. Toxicol Appl Pharmacol. 2000;166(1):24-35.

115. Rossman TG. Mechanism of arsenic carcinogenesis: an integrated approach. Mutat Res. 2003;533(1-2):37-65.

116. Waalkes MP, Ward JM, Diwan BA. Induction of tumors of the liver, lung, ovary and adrenal in adult mice after brief maternal gestational exposure to inorganic arsenic: promotional effects of postnatal phorbol ester exposure on hepatic and pulmonary, but not dermal cancers. Carcinogenesis. 2004;25(1):133-41.

117. Chen Y, Ahsan H. Cancer burden from arsenic in drinking water in Bangladesh. Am J Public Health. 2004;94(5):741-4.

118. Luo FJ, Luo ZD, Ma L. [A study on the relationship between drinking water with high arsenic content and incidence of malignant tumour in Heihe Village, western part of Huhehot, Inner Mongolia]. Zhonghua Liu Xing Bing Xue Za Zhi. 1995;16(5):289-91.

119. Tsai SM, Wang TN, Ko YC. Mortality for certain diseases in areas with high levels of arsenic in drinking water. Arch Environ Health. 1999;54(3):186-93.

120. Tsuda T, Babazono A, Yamamoto E, Kurumatani N, Mino Y, Ogawa $\mathrm{T}$, et al. Ingested arsenic and internal cancer: a historical cohort study followed for 33 years. Am J Epidemiol. 1995;141(3):198-209.

121. Occupational exposures in insecticide application, and some pesticides. IARC Working Group on the Evaluation of Carcinogenic Risks to Humans. Lyon, 16-23 October 1990. IARC Monogr Eval Carcinog Risks Hum. 1991;53:5-586. 